Research article

Open Access

\title{
A meta-analysis of the efficacy of fibromyalgia treatment according to level of care
}

\author{
Javier Garcia-Campayo 1,7, Jesus Magdalena2,7, Rosa Magallón3,7, Esther Fernández-García ${ }^{4,7}$, \\ Montserrat Salas ${ }^{5,7}$ and Eva Andrés 6,7
}

\author{
${ }^{1}$ Miguel Servet Hospital, University of Zaragoza, Zaragoza, Spain \\ 2Letux Health Centre, Letux, Zaragoza, Spain \\ ${ }^{3}$ Arrabal Health Centre, Zaragoza, Spain \\ 4Miguel Servet Hospital, University of Zaragoza, Zaragoza, Spain \\ ${ }^{5}$ Government of Aragon, Zaragoza, Spain \\ 6 University of Zaragoza, Zaragoza, Spain \\ ${ }^{7}$ Grupo Aragonés de Investigación en Atención Primaria, Red de Actividades Preventivas y de Promoción de la Salud (REDIAPP) (G06/128), Instituto \\ Aragonés de Ciencias de la Salud (IACS), Zaragoza, Spain
}

Corresponding author: Javier Garcia-Campayo, jgarcamp@arrakis.es

Received: 21 Mar 2008 Revisions requested: 30 Apr 2008 Revisions received: 20 May 2008 Accepted: 15 Jul 2008 Published: 15 Jul 2008

Arthritis Research \& Therapy 2008, 10:R81 (doi:10.1186/ar2455)

This article is online at: http://arthritis-research.com/content/10/4/R81

(c) 2008 Garcia-Campayo et al:; licensee BioMed Central Ltd.

This is an open access article distributed under the terms of the Creative Commons Attribution License (http://creativecommons.org/licenses/by/2.0), which permits unrestricted use, distribution, and reproduction in any medium, provided the original work is properly cited.

\begin{abstract}
Introduction The aim of this paper was to compare the efficacy of the treatments for fibromyalgia currently available in both primary care and specialised settings.

Methods Published reports of randomised controlled trials (RCTs) researching pharmacological and non-pharmacological treatments in patients with fibromyalgia were found in the MEDLINE, EMBASE, the Cochrane Central Register of Controlled Trials and Psychlnfo databases. The most recent electronic search was undertaken in June 2006.

Results We identified a total of 594 articles. Based on titles and abstracts, 102 full articles were retrieved, 33 of which met the inclusion criteria. These RCTs assessed 120 treatment interventions in 7789 patients diagnosed with primary fibromyalgia. Of them, $4505(57.8 \%)$ were included in the primary care group of our study and $3284(42.2 \%)$ in the specialised intervention group. The sample was mostly made up of middle-aged women, who have had fibromyalgia for a mean period of 6 to 10 years. The mean effect size of the efficacy of the 120 treatment interventions in patients with fibromyalgia

compared with controls was 0.49 (95\% confidence interval [Cl] $=0.39$ to $0.58 ; p<0.001)$. In the primary care group it was 0.46 $(95 \% \mathrm{Cl}=0.33$ to 0.58$)$ while in specialised care it was 0.53 $(95 \% \mathrm{Cl}=0.38$ to 0.69$)$, with no statistical significance in the differences. We analysed the efficacy of treatments by comparing primary and specialised care in the different fibromyalgia groups and there were no significant differences. The variables of the studies that affected the improvements in the efficacy of fibromyalgia treatment were low quality of the studies and a shorter duration of treatment. However, both factors were biased by the heterogeneity of the studies. Other variables that also improved outcome and were not biased by the heterogeneity of the studies, were younger age of the patients and shorter duration of the disorder. On the contrary, gender and type of treatment (pharmacological vs. psychological) did not affect outcome.

Conclusion Based on this meta-analysis and despite the heterogeneity of specialised care studies and of the other limitations described in this article, treating fibromyalgia in specialised care offers no clear advantages.
\end{abstract}

\section{Introduction}

Fibromyalgia is a chronic musculoskeletal pain disorder of unknown aetiology, characterised by widespread pain and muscle tenderness and often accompanied by fatigue, sleep disturbance and depressed mood [1,2]. With an estimated lifetime prevalence of approximately $2 \%$ in community samples [3], it accounts for $15 \%$ of outpatient rheumatology visits and $5 \%$ of primary care visits [4]. The prognosis for symptomatic recovery is generally poor [5]. A wide variety of interventions are used in the management of this disorder, although there is 
no clear consensus on the treatment of choice and fibromyalgia remains relatively refractory to treatment.

A number of meta-analyses and reviews have been conducted on the pharmacological [6-8] and non-pharmacological $[9,10]$ treatments available for fibromyalgia. The studies main objectives are to guide clinicians in their everyday practice using evidence-based decisions. However, the aim of our current study is rather different. The high prevalence and clinical impact of fibromyalgia makes it a significant public health problem given its high cost. In Spain and other public health systems, a difficult cost-benefit decision must be taken as to which level of the health care system these patients should be treated in: either in specialised settings, which many patients prefer, or in primary care, which is usually more cost-effective. To our knowledge, there is no published meta-analysis on this subject.

We carried out a systematic review and meta-analysis of all randomised controlled trials (RCTs) of pharmacological and non-pharmacological treatments that are available in standard primary care settings and those that are administered in standard secondary care settings of public health care systems in developed countries for the treatment of fibromyalgia. The aim of this paper is to compare the efficacy of the treatments for fibromyalgia available in both settings using the most important outcomes assessed in this disorder, such as pain, quality of life, depression, etc.

\section{Materials and methods}

We followed the QUOROM guidelines for reporting metaanalyses [11].

\section{Database search}

Published reports of RCTs researching pharmacological or non-pharmacological treatments in patients with fibromyalgia were found in the following databases: MEDLINE (19662006), EMBASE (1988-2006), The Cochrane Central Register of Controlled Trials (the Cochrane Library Issue 2006) and Psychinfo (1987-2006). Search strategy is summarised in the additional data file. The search was performed without language restrictions but was limited to RCTs in humans. The last electronic search was undertaken in June 2006. All primary and review articles, as well as their references, were reviewed independently in duplicate. The authors of the original reports were contacted for additional information where needed.

\section{Selection criteria}

Studies were screened for inclusion, by reviewing the title and published abstract, based on the following criteria:

\section{Type of participants}

The studies evaluated the treatment or management of fibromyalgia as indicated by the use of recognised diagnostic criteria, such as American College of Rheumatology (ACR) [1].
Despite the concept of primary fibromyalgia (patients in which fibromyalgia can not be explained by other medical disorders) not being accepted by the ACR, most studies on fibromyalgia, and many of the papers included in the meta-analysis, do accept this distinction. Therefore, it has been maintained to increase comparability.

\section{Types of studies}

The papers described a randomisation of treatment, placebo control and at least one group receiving an active (pharmacological or non-pharmacological) treatment.

\section{Types of interventions}

Treatment can be defined as pharmacological or non-pharmacological, and can be allocated to primary or specialised care. The duration of treatment was at least eight weeks.

\section{Types of outcomes}

Outcomes had to be measurable. One of the major problems in fibromyalgia is the wide variety of outcomes. Seven types of outcomes were included: pain, fatigue, quality of life, global function, anxiety/depression, insomnia and tender points. Each of them were assessed with several questionnaires.

Each study was reviewed in duplicate (by EF and JGC) for inclusion with substantial inter-rater agreement (kappa $=0.7$ ). Disagreements were resolved by a consensus agreement. Reviews and abstracts were not considered. The study selection process flowchart is summarised in Figure 1.

\section{Allocation \\ All studies included were allocated to a level of health care (primary care or specialised care) and category of treatment (pharmacological or non-pharmacological) by a consensus with substantial inter-rater agreement (kappa $=0.91)$ from a panel of two general practitioners (RM and JM), a psychiatrist (JGC) and a psychologist (EF). A treatment was considered to be available at the primary care level when most general prac- titioners from most Western national health services were able to provide that treatment without any specific training. Tables 1 and 2 summarise which treatments were allocated to the pri- mary and specialised care groups and to the pharmacological and non-pharmacological treatment groups. We have not included RCTs on acupuncture because of the recent meta- analyses showing that this treatment is not effective [10].}

\section{Validity assessment}

All included reports were then independently read by two reviewers (EF and JGC) who assessed the validity of the studies using the modified Oxford Scale (Table 3) [12,13]. The minimum score of an included trial was one and the maximum was six. Discrepancies were resolved by discussion or by consulting a third reviewer (RM). 


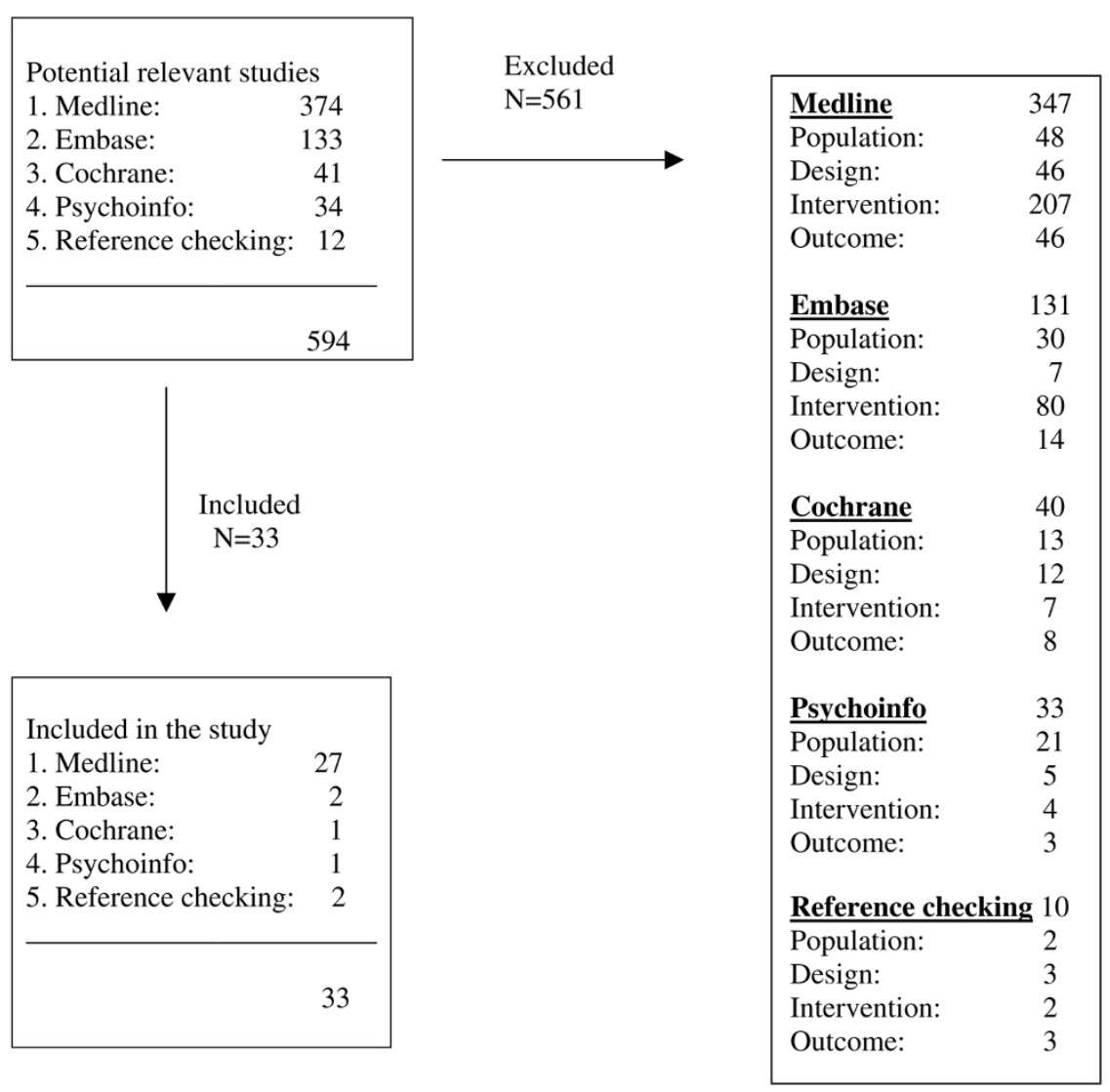

Flowchart showing the process of study selection.

\section{Data abstraction}

A data abstraction form was created and the following data were included: number of patients and controls, gender (percentage of women), age (median), diagnosis, time of evolution of the disorder (years), severity of the disorder, level of health care (primary care or specialised), kind of treatment (pharmacological or non pharmacological), duration of treatment, modified Oxford Scale ratings and outcomes (ratings in different used scales of quality of life, pain, depression, anxiety, etc).

\section{Meta-analyses}

Both dichotomous and continuous data were extracted. Continuous data were analysed as standardised differences in the means (SDM) with 95\% confidence intervals (Cl). Where mean values and standard deviations were not reported, the authors of the studies were contacted. If they did not reply and the data were presented graphically, data were extracted from the graphs. If this was not possible, the data were not considered. A random effects model was used by default. Analyses were performed using Comprehensive Meta-analysis, version 2 (Biostat, Englewood, NJ, USA). Data were graphically plotted using forest plots to evaluate treatment effects. Clinical heterogeneity was minimised using stringent diagnostic criteria for fibromyalgia and homogeneous criteria for the treat- ments and outcomes of the studies included in the metaanalysis.

\section{Results}

\section{Literature search and study selection}

We first performed our literature search in MEDLINE (374 hits), followed by EMBASE (133 hits), and subsequently in the Cochrane Library (41 hits) and in Psychinfo (34 hits). By checking references, we identified an additional 12 hits, resulting in a total of 594 articles (Figure 1). Based on titles and abstracts, 102 full articles were retrieved, 33 of which met the inclusion criteria [14-46]. These 33 studies are summarised in Table 4.

Of the 69 studies that were excluded 23 were not an RCT; the patient population of 28 were not primary fibromyalgia (but secondary fibromyalgia or allied conditions) or the fibromyalgia criteria used were not ACR criteria [1]; in 16 studies the intervention had a duration shorter than eight weeks or it was so specific that it was not available in standard Western health care systems [47]; and two studies did not use comparable outcome measures. There was seven types of outcomes used in the studies selected from 16 questionnaires or tests summarised in Table 5. 
Table 1

\begin{tabular}{ll}
\hline Allocation of treatments according to level of care \\
\hline Primary care & Secondary care \\
\hline Amitriptyline & Pirlindole \\
Tramadol & Tropisetron \\
Milnacipran & Dehydroepiandrosterone (DHEA) \\
Moclobemide & Pramipexole \\
Fluoxetine & Malic acid \\
Cyclobenzaprine & Rehabilitation \\
Nortriptyline & Laser treatment \\
Duloxetine & Hyperbaric oxygen therapy \\
Pregabaline & Bright light treatment \\
Zolpidem & Aerobic exercise \\
& Exercise \\
& Stress-reduction treatment \\
& Chiropractic management \\
& Cognitive behavioural therapy \\
& Cognitive educational therapy \\
& Education training \\
& Behavioural insomnia therapy \\
&
\end{tabular}

\section{Methodological quality of the included studies}

Only 11 of the 33 included studies (33.3\%) showed a rating of $5+$ on the modified Oxford Scale, that is, a score of high methodological quality. Most of them (nine of 11) were pharmacological studies and the remaining two studies were psychological interventions. Many of them were recent studies, carried out in 2004 and 2005 (six of 11), as can be seen in Tables 4 and 6 . The most commonly absent items were an adequate description of the flow of patients and adequate description of double blinding.

\section{Study characteristics}

The review selected 33 RCTs that assessed 120 treatment interventions on 7789 patients diagnosed with primary fibromyalgia according to ACR criteria [1]. Of these, 4505 (57.8\%) were included in the primary care group and $3284(42.2 \%)$ in the specialised intervention group. The characteristics of the patients included in these studies are summarised in Table 6. The sample was made up of middle-aged women, who had the disorder for between six and 10 years $(51.9 \%)$, treated mainly with pharmacological approaches (73.3\%). The outcome types most frequently assessed were pain (26.6\%) and global function (23.4\%). Most of the patients were from studies carried out in the USA and Canada (63.6\%) and were published after 2000 (61.5\%). There were no significant differences in any of the variables studied between control and intervention groups.

Table 2

Pharmacological and non-pharmacological treatments

\begin{tabular}{ll}
\hline Pharmacological treatments & Non-pharmacological treatments \\
\hline Amitriptyline & Hyperbaric oxygen therapy \\
Cyclobenzaprine & Bright light treatment \\
Dehydroepiandrosterone (DHEA) & Aerobic exercise \\
Duloxetine & Education training \\
Fluoxetine & Behavioural therapy \\
Malic acid & Cognitive behavioural therapy \\
Milnacipran & Cognitive educational therapy \\
Moclobemide & Exercise \\
Nortriptyline & Rehabilitation \\
Pirlindole & Music vibration \\
Pramipexole & Chiropractic management \\
Pregabaline & Stress-reduction treatment \\
Tramadol & Behavioural insomnia therapy \\
Tropisetron & Laser \\
Zolpidem & \\
\hline
\end{tabular}


Table 3

Modified Oxford Scale. Validit
Randomisation
0 None
1 Mentioned
2 Described and adequate
Concealment of allocation
0 None
1 Yes
Double blinding
0 None
1 Mentioned
2 Described and adequate
2 Described and adequate

The mean effect size of the efficacy of the 120 treatment interventions on patients with fibromyalgia compared with efficacy in controls, regardless of the outcome type assessed or the questionnaire used, was $0.49(95 \% \mathrm{Cl}=0.39$ to $0.58 ; \mathrm{p}<$ $0.001)$. This is a medium size effect [62], but it is significant. When we compared the efficacy of these treatments on fibromyalgia, after allocating the treatments to primary or specialised level of care, regardless of the type of outcome assessed or the questionnaire used, mean effect size of efficacy in primary care was $0.46(95 \% \mathrm{Cl}=0.33$ to 0.58$)$ while in specialised care was $0.53(95 \% \mathrm{Cl}=0.38$ to 0.69 . These differences are not significant.

When we analysed the efficacy of treatments on the different fibromyalgia outcome types (Table 7), we observed that there is an overlapping of the interval scores comparing primary and specialised care for all outcome types. This means that there are no significant differences. There are insignificant differences favouring secondary or specialised care for tender points (mean $=0.28 ; 95 \% \mathrm{Cl}=0.12$ to 0.68 for primary care; mean $=0.50,95 \% \mathrm{Cl}=0.0$ to 1.0 for specialised care) and pain (mean $=0.48,95 \% \mathrm{Cl}=0.30$ to 0.66 for primary care; mean $=0.73,95 \% \mathrm{Cl}=0.41$ to 1.05 for specialised care). On the other hand, there are insignificant differences in favour of primary care for insomnia (mean $=0.57,95 \% \mathrm{Cl}=0.15$ to 0.99 for primary care; mean $=-0.18,95 \% \mathrm{Cl}=-0.62$ to 0.27 for specialised care), anxiety/depression (mean $=0.59,95 \%$
$\mathrm{Cl}=0.10$ to 1.08 for primary care; mean $=0.40,95 \% \mathrm{Cl}=$ 0.12 to 0.67 for specialised care), and fatigue (mean $=0.30$, $95 \% \mathrm{Cl}=0.05$ to 0.56 for primary care; mean $=0.22,95 \% \mathrm{Cl}$ $=-0.08$ to 0.52 for specialised care). For specialized care, there are minimal differences also nonsignificant (surely the cause is higher heterogeneity in these studies). Global function, thought to capture the whole impact of the disease, was quite similar in both levels of care ( 0.53 in primary care; 0.54 in specialised care). The quality of life outcome could not be compared because there were no studies in primary care assessing this variable.

As an example, we have included the efficacy of the treatments allocated to both levels of care in the outcome of pain in patients with fibromyalgia (Figure 2). This outcome is one of the most important in this disorder and the most thoroughly assessed in the studies reviewed. We can observe that there are insignificant differences favouring specialised care $(0.73$ for specialised care; 0.48 for primary care). However, in this figure, we can also see that heterogeneity in specialised care treatment is higher than in primary care treatment. In fact, there are two studies $[40,46]$ with outcomes of 3.18 and 2.49 , respectively, which are the source of this difference. This higher heterogeneity in specialised care treatments compared with primary care treatments is also found in the remaining types of outcome.

In Table 8 we can see the influence of moderating variables on all of the outcomes assessed (overall efficacy), on the specific outcome Global function and on the Fibromyalgia Impact Questionnaire (FIQ). Obviously, we could have included other outcomes and questionnaires but owing to the great amount of information, we selected these variables because they seem to be the most used in assessing the efficacy of fibromyalgia treatments. The results when the other outcomes or questionnaires are analysed are quite similar.

In Table 8 we can also see that an improvement in the methodological quality of the studies is accompanied by a reduction in size effect in the Global Function outcome (the same is found for FIQ scores or for overall efficacy), owing to lesser heterogeneity. Type of treatment, whether pharmacological or non-pharmacological, did not modify the mean effect size in any of the three variables assessed.

On the contrary, shorter length of treatment favours differences that increase size effect. However, these differences can be explained by higher heterogeneity in the studies with shorter treatments, as can be seen on Figure 2 and not by a decrease in the therapeutic effect in longer treatments. With regard to mean participant age, we can observe higher improvement in all outcomes assessed in younger patients. However, the number of studies that evaluate the period of age extremes (young and older people) and assess overall efficacy is low. There are no differences in outcome in relation to 
Table 4

Characteristics of the 33 selected randomised controlled trials and the patients studied in them

\begin{tabular}{|c|c|c|c|c|c|c|c|c|c|c|c|c|}
\hline $\mathrm{N}$ & $\begin{array}{c}\text { Randomized } \\
\text { controlled } \\
\text { trial }\end{array}$ & Year & Country & Treatment & Level of care & $\begin{array}{c}\% \text { of } \\
\text { women }\end{array}$ & $\begin{array}{c}\text { Mean } \\
\text { age }\end{array}$ & $\begin{array}{c}\text { Length of } \\
\text { treatment } \\
\text { (years) }\end{array}$ & $\begin{array}{c}\text { Simple } \\
\text { size }\end{array}$ & $\begin{array}{l}\text { Oxford } \\
\text { scoring } \\
\text { (quality) }\end{array}$ & $\begin{array}{c}\text { Duration } \\
\text { of } \\
\text { disease } \\
\text { at } \\
\text { baseline } \\
\text { (years) }\end{array}$ & $\begin{array}{c}\text { Instruments } \\
\text { used } \\
\text { (outcome } \\
\text { assessed) }\end{array}$ \\
\hline 1 & Carette & 94 & Canada & $\begin{array}{l}\text { Amitryptiline } \\
\text { Cyclobenzaprine }\end{array}$ & Primary care & 93.8 & 44.4 & 24 & 208 & 3 & 7.7 & $\begin{array}{l}\text { Mc Gill-BPI } \\
\text { (p) SIP (gf) }\end{array}$ \\
\hline 2 & Russell & 94 & USA & Malic acid & $\begin{array}{l}\text { Specialised } \\
\text { care }\end{array}$ & 90 & 49.5 & 8 & 24 & 3 & & $\underset{(t p)}{\operatorname{VAS}(p)} \operatorname{TPI}$ \\
\hline 3 & Wolfe & 94 & USA & Fluoxetine & Primary care & 100 & 50.4 & 3 & 42 & 5 & 13 & $\underset{(\mathrm{ad})}{\mathrm{TPI}(\mathrm{tp})} \mathrm{BDI}$ \\
\hline 4 & Carette & 95 & Canada & Amitryptiline & Primary care & 95.5 & 43.8 & 8 & 22 & 2 & 6.9 & $\begin{array}{l}\text { VAS (p) VAS } \\
\text { (i) VAS (gf) }\end{array}$ \\
\hline 5 & Chesky & 95 & USA & Music vibration & $\begin{array}{l}\text { Specialised } \\
\text { care }\end{array}$ & 92.6 & 48.8 & 30 minutes & 26 & 3 & 11 & $\underset{(t p)}{\operatorname{VAS}(p)} \operatorname{TPI}$ \\
\hline 6 & Goldenberg & 96 & USA & $\begin{array}{l}\text { Fluoxetine } \\
\text { Amitryptiline }\end{array}$ & Primary care & 90.3 & 43 & 6 & 31 & 5 & 5.7 & $\begin{array}{c}\text { VAS (p) FIQ } \\
\text { (GF) BDI } \\
\text { (ad) VAS (i) } \\
\text { VAS (gf) } \\
\text { VAS (f) TPI } \\
\text { (tp) }\end{array}$ \\
\hline 7 & Ginsberg & 96 & Belgium & Amitryptiline & Primary care & 82.5 & 46 & 8 & 46 & 2 & 32 & $\begin{array}{l}\text { VAS (p) VAS } \\
\text { (i) TPI (tp) } \\
\text { VAS (f) VAS } \\
\text { (gf) NTP (tp) }\end{array}$ \\
\hline 8 & Moldofsky & 96 & Canada & Zolpidem & Primary care & 95 & 42 & 2.5 & 19 & 4 & & $\operatorname{NTP}_{\text {(i) }}$ (tp) PGI \\
\hline 9 & Vlayen & 96 & Holland & $\begin{array}{l}\text { Cognitive } \\
\text { behavioural } \\
\text { therapy } \\
\text { Education } \\
\text { training }\end{array}$ & $\begin{array}{l}\text { Specialised } \\
\text { care }\end{array}$ & 87 & 44 & 6 & 131 & 5 & 10 & $\mathrm{BDI}(\mathrm{ad})$ \\
\hline 10 & Wigers & 96 & Norway & $\begin{array}{l}\text { Aerobic exercise } \\
\text { Stress-reduction } \\
\text { treatment }\end{array}$ & $\begin{array}{l}\text { Specialised } \\
\text { care }\end{array}$ & 92 & 44 & 14 & 48 & 3 & 10 & $\begin{array}{l}\text { VAS (p) VAS } \\
\text { (i) VAS (f) }\end{array}$ \\
\hline 11 & Pearl & 96 & Canada & $\begin{array}{l}\text { Bright light } \\
\text { treatment }\end{array}$ & $\begin{array}{l}\text { Specialised } \\
\text { care }\end{array}$ & 100 & 38 & 10 & 14 & 2 & 5 & $\begin{array}{l}\text { VAS (p) VAS } \\
\text { (f) VAS (i) }\end{array}$ \\
\hline 12 & Kelli & 97 & Canada & $\begin{array}{l}\text { Chiropractic } \\
\text { treatment }\end{array}$ & $\begin{array}{l}\text { Specialised } \\
\text { care }\end{array}$ & - & 49 & 4 & 19 & 4 & 8 & $\underset{(t p)}{\operatorname{VAS}(p)}$ NTP \\
\hline 13 & Hannonen & 98 & Finland & $\begin{array}{l}\text { Moclobemide } \\
\text { Amitryptiline }\end{array}$ & Primary care & 100 & 49 & 12 & 130 & 5 & 11.2 & $\begin{array}{l}\text { NTP (tp) } \\
\text { VAS (p) VAS } \\
\text { (f) VAS (i) }\end{array}$ \\
\hline 14 & Yavuzer & 98 & Turkey & Moclobemide & Primary care & 58 & 33 & 6 & 60 & 1 & & TPI (tp) \\
\hline 15 & Ginsberg & 98 & Belgium & Pirlindole & $\begin{array}{l}\text { Specialised } \\
\text { care }\end{array}$ & 85 & 40 & 4 & 61 & 4 & 2.9 & $\begin{array}{l}\text { VAS (p) TPI } \\
\text { (tp) VAS (gf) }\end{array}$ \\
\hline 16 & Russell & 00 & USA & Tramadol & Primary care & 94 & 49 & 6 & 69 & 4 & 4.7 & $\begin{array}{l}\text { VAS (p) FIO } \\
\text { (gf) NTP (tp) }\end{array}$ \\
\hline 17 & Heymann & 01 & Brazil & $\begin{array}{l}\text { Amitryptiline } \\
\text { Nortryptiline }\end{array}$ & Primary care & 100 & 50 & 8 & 118 & 4 & & $F \underset{(\mathrm{tp})}{\mathrm{FIO}}$ \\
\hline 18 & Färber & 01 & Germany & Tropisetron & $\begin{array}{l}\text { Specialised } \\
\text { care }\end{array}$ & 92 & 48 & 1.5 & 403 & 3 & 11 & $\underset{(t p)}{\operatorname{Vas}(p)}$ NTP \\
\hline 19 & Gowans & 01 & Canada & Exercise & $\begin{array}{l}\text { Specialised } \\
\text { care }\end{array}$ & 88 & 47 & 23 & 50 & 3 & 9 & $\begin{array}{l}\text { FIO (gf) BDI } \\
\text { (ad) STAI } \\
\text { (ad) NTP (tp) }\end{array}$ \\
\hline 20 & Mannerkorpi & 01 & Sweden & $\begin{array}{l}\text { Education } \\
\text { training }\end{array}$ & $\begin{array}{l}\text { Specialised } \\
\text { care }\end{array}$ & 100 & 46 & 24 & 58 & 4 & 8.7 & $\begin{array}{l}\text { FIO (gf) } \\
\text { QOLS (ql) }\end{array}$ \\
\hline 21 & Gür & 02 & Turkey & $\begin{array}{l}\text { Laser } \\
\text { Amitryptiline }\end{array}$ & $\begin{array}{c}\text { Primary care } \\
\text { (Amytriptiline) } \\
\text { - Specialised } \\
\text { care (laser) }\end{array}$ & 80 & 30 & 8 & 75 & 3 & 4.6 & $\begin{array}{l}\text { HADS (ad) } \\
\text { FIQ (gf) }\end{array}$ \\
\hline
\end{tabular}




\begin{tabular}{|c|c|c|c|c|c|c|c|c|c|c|c|c|}
\hline 22 & Joaquim & 02 & Sweden & $\begin{array}{l}\text { Education } \\
\text { training } \\
\text { Behavioural } \\
\text { therapy }\end{array}$ & $\begin{array}{l}\text { Specialised } \\
\text { care }\end{array}$ & 100 & 45 & 12 & 53 & 6 & 3.6 pain & $\begin{array}{l}\text { FIO (gf) Mc } \\
\text { Gill (p) }\end{array}$ \\
\hline 23 & King & 02 & Canada & $\begin{array}{l}\text { Exercise } \\
\text { Education } \\
\text { training }\end{array}$ & $\begin{array}{l}\text { Specialised } \\
\text { care }\end{array}$ & 100 & 46 & 12 & 152 & 4 & & $\mathrm{FIO} \underset{(\mathrm{tp})}{(\mathrm{gf})} \mathrm{NTP}$ \\
\hline 24 & Lemstra & 05 & Canada & Rehabilitation & $\begin{array}{l}\text { Specialised } \\
\text { care }\end{array}$ & 84.5 & 49.5 & 6 & 79 & 3 & 10 & $\begin{array}{c}\operatorname{VAS}(p) \text { BDI } \\
(\mathrm{ad})\end{array}$ \\
\hline 25 & Schachter & 03 & Canada & $\begin{array}{l}\text { Aerobic exercise } \\
\text { (long-term and } \\
\text { short-term) }\end{array}$ & $\begin{array}{l}\text { Specialised } \\
\text { care }\end{array}$ & 100 & 42 & 16 & 143 & 4 & 3.5 & $\underset{(\mathrm{gf})}{\operatorname{VAS}(p)} \mathrm{FIO}$ \\
\hline 26 & Arnold & 04 & USA & Duloxetine & Primary care & 88 & 49 & 12 & 207 & 6 & 8.9 & $\begin{array}{c}\text { BDI (ad) BPI } \\
\text { (ad) NTP (tp) } \\
\text { CGI (gf) FIO } \\
\text { (gf) }\end{array}$ \\
\hline 27 & Yildiz & 04 & Turkey & $\begin{array}{l}\text { Hyperbaric } \\
\text { oxigen therapy }\end{array}$ & $\begin{array}{l}\text { Specialised } \\
\text { care }\end{array}$ & 70 & 40 & 2.5 & 50 & 2 & 4.5 & $\begin{array}{c}\operatorname{VAS}(p) \text { NTP } \\
(\mathrm{tp})\end{array}$ \\
\hline 28 & Crofford & 05 & USA & Pregabaline & Primary care & 92 & 48.5 & 8 & 529 & 5 & 9 & $\operatorname{VAS}(p)$ MAF \\
\hline 29 & Arnold & 05 & USA & Duloxetine & Primary care & 100 & 50 & 12 & 354 & 5 & & BPI (ad) \\
\hline 30 & Gendreau & 05 & USA & Milnacipran & Primary care & 98 & 47 & 12 & 125 & 6 & 4.1 & FIO (gf) \\
\hline 31 & Finckh & 05 & $\begin{array}{l}\text { Switzerla } \\
\text { nd }\end{array}$ & $\begin{array}{l}\text { Dehydroepiandr } \\
\text { osterone (DHA) }\end{array}$ & $\begin{array}{l}\text { Specialised } \\
\text { care }\end{array}$ & 100 & 59 & 12 & 52 & 6 & 13 & $\begin{array}{l}\text { HADS (ad) } \\
\text { VAS (f) }\end{array}$ \\
\hline 32 & Holman & 05 & USA & Pramipexole & $\begin{array}{l}\text { Specialised } \\
\text { care }\end{array}$ & 94.4 & 48.5 & 14 & 60 & 6 & 8.4 & $\begin{array}{l}\text { BDI (ad) } \\
\text { HAMD (ad) } \\
\text { TPI (tp) FIO } \\
\text { (gf) }\end{array}$ \\
\hline 33 & Edinger & 05 & USA & $\begin{array}{l}\text { Cognitive } \\
\text { behavioural } \\
\text { therapy Sleep } \\
\text { hygiene }\end{array}$ & $\begin{array}{l}\text { Specialised } \\
\text { care }\end{array}$ & 100 & 49 & 6 & 47 & 3 & & $\begin{array}{c}\text { Mc Gill (p) } \\
\text { BPI (ad) SF- } \\
36 \text { (ql) }\end{array}$ \\
\hline
\end{tabular}

Outcome types: P, Pain; QL, Quality of life; AD, Anxiety-depression; I, Insomnia; TP, Tender points; F, Fatigue; GF, Global Function.

Questionnaires: Mc Gill PQ, Mc Gill Pain Questionnaire; BPI, Brief Pain Inventory; VAS, Visual Analogue Scale; QOLS, Quality of Life Scale; BDI, Beck Depression Inventory; HADS, Hospital Anxiety and Depression Scale; HDS, Hamilton Depression Scale; STAl, State-trait Anxiety Inventory; PGI, Patient Global Impression; TPI, Tender Points Index; MAF, Multi-dimensional Assessment of Fatigue; FIQ, Fibromyalgia Impact Questionnaire; CGIS, Clinical Global Impression of Severity; SIP, Sickness Impact Profile.

gender in any of the three variables evaluated. Finally, the duration of the disorder influences the outcome: a shorter evolution of the disease is associated with higher improvement in any outcome. Again, the number of these kinds of studies is low and heterogeneity is greater, so interpretation of the results is more subjective.

Statistical heterogeneity has been assessed by inconsistence [63]; in our study this is $75 \%$, which is considered to be highly inconsistent. In these cases, the use of random effects analysis is recommended, which we did. A funnel plot between standard error and mean standardised difference, a quality measure to assess publication bias, indicates that most studies are distributed around the central line and are placed in the middle of the graph. There are some small sample studies scattered on the right and on the lower part of the graph that imbalance the weight towards positive values.

\section{Discussion}

There have been studies assessing multi-modal treatments in primary care [64] and trying to improve the efficacy of primary care treatments for patients with fibromyalgia through better communication [65]. However, to the best of our knowledge this is the first meta-analysis on the efficacy of the treatment of fibromyalgia according to level of care. The clinical and economical relevance of this disorder makes this a key question of research in free, universal health systems in which general practitioners are the gateway to the system. Prevalent and chronic disorders such as fibromyalgia are a huge cost to the health care system [3] and it is necessary to demonstrate whether treatment in a specialised care setting improves the outcome compared with its routine management in a primary care setting.

Only 33 studies from 594 papers examined met the inclusion criteria of our study. These 33 RCTs assessed 120 treatment interventions on patients diagnosed with primary fibromyalgia, $4505(57.8 \%)$ of whom were allocated to primary care and $3284(42.2 \%)$ to specialised care. The sample was made up of middle-aged women, with an average duration of the disorder of six to 10 years, mainly treated with pharmacological approaches. Most of the studies were carried out in the USA 
Table 5

Questionnaires and outcome types used in the studies selected

\begin{tabular}{|c|c|}
\hline Type of outcome & Questionnaires \\
\hline \multirow[t]{3}{*}{ Pain $(p)$} & McGill Pain Questionnaire [48] \\
\hline & Brief Pain Inventory [49] \\
\hline & Visual Analogue Scale [50] \\
\hline \multirow[t]{2}{*}{ Quality of life (ql) } & SF-36 [51] \\
\hline & Quality of Life Scale (QOLS) [52] \\
\hline \multirow[t]{4}{*}{ Anxiety and depression (ad) } & Beck Depression Inventory [53] \\
\hline & Hospital Anxiety and Depression Scale [54] \\
\hline & Hamilton Depression Scale [55] \\
\hline & State-trait Anxiety Inventory [56] \\
\hline \multirow[t]{2}{*}{ Insomnia (i) } & Visual Analog Scale [50] \\
\hline & Patient Global Impression [57] \\
\hline \multirow[t]{2}{*}{ Tender points (tp) } & Tender Points Index [58] \\
\hline & Number of Tender Points according to American College of Rheumatology criteria [1] \\
\hline \multirow[t]{2}{*}{ Fatigue ( $\mathrm{f}$ ) } & Visual Analog Scale [50] \\
\hline & Multi-dimensional Assessment of Fatigue [59] \\
\hline \multirow[t]{4}{*}{ Global Function (gf) } & Visual Analog Scale [50] \\
\hline & Fibromyalgia Impact Questionnaire [60] \\
\hline & Clinical Global Impression of Severity [57] \\
\hline & Sickness Impact Profile (SIP) [61] \\
\hline
\end{tabular}

and Canada and were published after 2000. Owing to the great variety of outcomes and questionnaires used to assess the patients, we have summarised the results of the most frequently used in the studies revised: global function, pain and $\mathrm{FIQ}$. The quality of the studies was rather low with only onethird of them rating $5+$ on the Oxford Scale.

The studies by Yildiz and colleagues [40] and Edinger and colleagues [46] could be considered as "outliers" because the treatments assessed in both studies were much more efficacious than the other treatments allocated to specialised care, but the size sample in both studies was small and the duration of treatment somewhat short. However, we have not ruled out these two studies from the meta-analysis for the following reasons:

- These studies fulfil the stringent selection criteria of the metaanalysis. Methodological quality was rated independently and this variable is not an exclusion criteria.

-We expected this meta-analysis to show great heterogeneity owing to the different kinds of treatments included. We can not eliminate these studies merely as a result of their heterogeneity, since they are as valuable as the other studies included. We have used a random effects model for the analysis.

- Both studies assess non-pharmacological treatments and both were allocated to specialised care. To exclude them could bias the study towards pharmacological treatments and primary care.

- We recalculated the meta-analysis excluding these two studies and the results were the same: there were no significant differences in the efficacy of the treatments for fibromyalgia when comparing primary care and specialised care.

Our meta-analysis demonstrates that there are no differences in the overall outcome of fibromyalgia regardless of the level of care in which the patient is treated. This article only summarises some outcomes and questionnaires, but we have not found differences favouring either specialised or primary care for any of the seven outcomes or the many questionnaires assessed. In the case of quality of life, the two levels of care could not be compared. We consider that the external validity of these data is high because the selection criteria of the studies allow it to be generalised to most western health services. However, with respect to internal validity, this data should be 


\section{Characteristics of the patients included in the meta-analysis}

\begin{tabular}{|c|c|c|c|c|c|c|}
\hline & Total & $\%$ & Control group & $\%$ & Intervention group & $\%$ \\
\hline \multicolumn{7}{|l|}{ Level of care } \\
\hline Primary care & 4505 & 57.8 & 2127 & 57.6 & 2378 & 58.1 \\
\hline Specialised care & 3284 & 42.2 & 1567 & 42.4 & 1717 & 41.9 \\
\hline Overall & 7789 & 100.0 & 3694 & 100.0 & 4095 & 100.0 \\
\hline \multicolumn{7}{|l|}{ Kind of treatment } \\
\hline Pharmacological & 5706 & 73.3 & 2684 & 72.7 & 3022 & 73.8 \\
\hline Non-pharmacological & 2083 & 26.7 & 1010 & 27.3 & 1073 & 26.2 \\
\hline Overall & 7789 & 100.0 & 3694 & 100.0 & 4095 & 100.0 \\
\hline \multicolumn{7}{|l|}{ Outcome assessed } \\
\hline Anxiety/depression & 1195 & 15.3 & 570 & 15.4 & 625 & 15.3 \\
\hline Quality of life & 115 & 1.5 & 51 & 1.4 & 64 & 1.6 \\
\hline Pain & 2074 & 26.6 & 980 & 26.5 & 1094 & 26.7 \\
\hline Fatigue & 650 & 8.3 & 320 & 8.7 & 330 & 8.1 \\
\hline Tender points & 1533 & 19.7 & 738 & 20.0 & 795 & 19.4 \\
\hline Insomnia & 397 & 5.1 & 196 & 5.3 & 201 & 4.9 \\
\hline Global function & 1825 & 23.4 & 839 & 22.7 & 986 & 24.1 \\
\hline Overall & 7789 & 100.0 & 3694 & 100.0 & 4095 & 100.0 \\
\hline \multicolumn{7}{|l|}{ Methodological quality } \\
\hline 1 to 2 & 595 & 7.6 & 289 & 7.8 & 306 & 7.5 \\
\hline 3 to 4 & 3396 & 43.6 & 1577 & 42.7 & 1819 & 44.4 \\
\hline 5 to 6 & 3798 & 48.8 & 1828 & 49.5 & 1970 & 48.1 \\
\hline Overall & 7789 & 100.0 & 3694 & 100.0 & 4095 & 100.0 \\
\hline \multicolumn{7}{|l|}{ Length of treatment (weeks) } \\
\hline 0 to 8 & 3644 & 46.8 & 1750 & 47.4 & 1894 & 46.3 \\
\hline 09 to 16 & 3467 & 44.5 & 1678 & 45.4 & 1789 & 43.7 \\
\hline 17 to 24 & 678 & 8.7 & 266 & 7.2 & 412 & 10.1 \\
\hline Overall & 7789 & 100.0 & 3694 & 100.0 & 4095 & 100.0 \\
\hline \multicolumn{7}{|l|}{ Age } \\
\hline 30 to 39 & 253 & 3.2 & 125 & 3.4 & 128 & 3.1 \\
\hline 40 to 49 & 6662 & 85.5 & 3140 & 85.0 & 3522 & 86.0 \\
\hline 50 to 59 & 874 & 11.2 & 429 & 11.6 & 445 & 10.9 \\
\hline Overall & 7789 & 100.0 & 3694 & 100.0 & 4095 & 100.0 \\
\hline \multicolumn{7}{|l|}{ Percentage of women } \\
\hline$<80$ & 151 & 1.9 & 73 & 2.0 & 78 & 1.9 \\
\hline 80 to 89 & 2258 & 29.0 & 1111 & 30.1 & 1147 & 28.0 \\
\hline
\end{tabular}


Arthritis Research \& Therapy Vol 10 No 4 Garcia-Campayo et al.

Table 6 (Continued)

\section{Characteristics of the patients included in the meta-analysis}

$\begin{array}{rllllll}90 \text { to } 99 & 2874 & 36.9 & 1297 & 35.1 & 1577 & 38.5 \\ 100 & 2506 & 32.2 & 1213 & 32.8 & 1293 & 31.6 \\ \text { Overall } & 7789 & 100.0 & 3694 & 100.0 & 4095 & 100.0\end{array}$

Duration of the disorder (years)

$\begin{array}{rllcccc}0 \text { to } 5 & 1459 & 25.3 & 710 & 26.3 & 749 & 24.5 \\ 6 \text { to } 10 & 2987 & 51.9 & 1344 & 49.7 & 1643 & 53.8 \\ 11 \text { to } 15 & 1310 & 22.8 & 649 & 24.0 & 661 & 21.7 \\ \text { Overall } & 5756 & 100.0 & 2703 & 100.0 & 3053 & 100.0\end{array}$

Country

$\begin{array}{rcl}\text { Germany } & 410 & 5.3 \\ \text { Belgium } & 459 & 5.9 \\ \text { Brasil } & 278 & 3.6 \\ \text { Canada } & 1655 & 21.2 \\ \text { Finland } & 488 & 6.3 \\ \text { Holland } & 174 & 2.2 \\ \text { Norway } & 195 & 2.5 \\ \text { Sweden } & 254 & 3.3 \\ \text { Switzerland } & 276 & 3.5 \\ \text { Turkey } & 298 & 3.8 \\ \text { USA } & 3302 & 42.4 \\ \text { Overall } & 7789 & 100.0\end{array}$

$\begin{array}{ll}206 & 5.6 \\ 216 & 5.8 \\ 132 & 3.6 \\ 737 & 20.0 \\ 240 & 6.5 \\ 86 & 2.3 \\ 102 & 2.8 \\ 126 & 3.4 \\ 135 & 3.7 \\ 148 & 4.0 \\ 1566 & 42.4 \\ 3694 & 100.0\end{array}$

$\begin{array}{ll}204 & 5.0 \\ 243 & 5.9 \\ 146 & 3.6 \\ 918 & 22.4 \\ 248 & 6.1 \\ 88 & 2.1 \\ 93 & 2.3 \\ 128 & 3.1 \\ 141 & 3.4 \\ 150 & 3.7 \\ 1736 & 42.4 \\ 4095 & 100.0\end{array}$

Year of publication

$\begin{array}{rclclcl}1994 & 620 & 8.0 & 234 & 6.3 & 386 & 9.4 \\ 1995 & 178 & 2.3 & 86 & 2.3 & 92 & 2, .2 \\ 1996 & 1306 & 16.8 & 637 & 17.2 & 669 & 16.3 \\ 1997 & 38 & 0.5 & 18 & 0.5 & 20 & 0.5 \\ 1998 & 724 & 9.3 & 349 & 9.4 & 375 & 9.2 \\ 2000 & 207 & 2.7 & 102 & 2.8 & 105 & 2.6 \\ 2001 & 926 & 11.9 & 460 & 12.5 & 466 & 11.4 \\ 2002 & 780 & 10.0 & 372 & 10.1 & 408 & 10.0 \\ 2003 & 392 & 5.0 & 196 & 5.3 & 196 & 4.8 \\ 2004 & 1241 & 15.9 & 621 & 16.8 & 620 & 15.1 \\ 2005 & 1377 & 17.7 & 619 & 16.8 & 758 & 18.5 \\ \text { Overall } & 7789 & 100.0 & 3694 & 100.0 & 4095 & 100.0\end{array}$

analysed cautiously because statistical heterogeneity was important for specialised care studies whereas primary care studies show great homogeneity. In any case, the study points to moderate efficacy of any of the treatments described for fibromyalgia and similar efficacy in both primary and specialised levels of care.

Two of the variables that improve treatment efficacy in fibromyalgia are low quality of the studies and shorter duration of 
Table 7

\begin{tabular}{|c|c|c|c|c|c|c|c|c|c|c|c|c|c|c|c|c|c|c|c|}
\hline \multirow{2}{*}{\multicolumn{2}{|c|}{$\begin{array}{c}\begin{array}{c}\text { Global } \\
\text { function }\end{array} \\
\begin{array}{c}\text { Low-Up } \\
\text { Limit }\end{array}\end{array}$}} & \multicolumn{3}{|c|}{ Pain } & \multicolumn{3}{|c|}{ Tender points } & \multicolumn{3}{|c|}{ Quality of life } & \multicolumn{3}{|c|}{$\begin{array}{c}\text { Anxiety/ } \\
\text { depression }\end{array}$} & \multicolumn{3}{|c|}{ Insomnia } & \multicolumn{3}{|c|}{ Fatigue } \\
\hline & & \multirow{2}{*}{$\begin{array}{c}\begin{array}{c}\text { Std } \\
\text { dif in } \\
\text { mea } \\
\text { ns }\end{array} \\
0.48\end{array}$} & \multicolumn{2}{|c|}{$\begin{array}{l}\text { Low-Up } \\
\text { Limit }\end{array}$} & \multirow{2}{*}{$\begin{array}{c}\begin{array}{c}\text { Std } \\
\text { dif in } \\
\text { mea } \\
\text { ns }\end{array} \\
0.28\end{array}$} & \multicolumn{2}{|c|}{$\begin{array}{l}\text { Low-Up } \\
\text { Limit }\end{array}$} & \multirow{2}{*}{$\begin{array}{c}\text { Std } \\
\text { dif in } \\
\text { mea } \\
\text { ns }\end{array}$} & \multicolumn{2}{|c|}{$\begin{array}{l}\text { Low-Up } \\
\text { Limit }\end{array}$} & \multirow{2}{*}{$\begin{array}{c}\begin{array}{c}\text { Std } \\
\text { dif in } \\
\text { mea } \\
\text { ns }\end{array} \\
\mathbf{0 . 5 9}\end{array}$} & \multicolumn{2}{|c|}{$\begin{array}{l}\text { Low-Up } \\
\text { Limit }\end{array}$} & \multirow{2}{*}{$\begin{array}{c}\begin{array}{c}\text { Std } \\
\text { dif in } \\
\text { mea } \\
\text { ns }\end{array} \\
\mathbf{0 . 5 7}\end{array}$} & \multicolumn{2}{|c|}{$\begin{array}{l}\text { Low-Up } \\
\text { Limit }\end{array}$} & \multirow{2}{*}{$\begin{array}{c}\begin{array}{c}\text { Std } \\
\text { dif in } \\
\text { mea } \\
\text { ns }\end{array} \\
\mathbf{0 . 3 0}\end{array}$} & \multicolumn{2}{|c|}{$\begin{array}{l}\text { Low-Up } \\
\text { Limit }\end{array}$} \\
\hline 0.30 & 0.76 & & 0.30 & 0.66 & & $0 . \overline{12}$ & 0.68 & & & & & 0.10 & 1.08 & & 0.15 & 0.99 & & 0.05 & 0.56 \\
\hline 0.32 & 0.77 & 0.73 & 0.41 & 1.05 & 0.50 & 0.00 & 1.00 & 1.22 & 0.49 & 1.95 & 0.40 & 0.12 & 0.67 & $\overline{0.18}$ & $0 . \overline{62}$ & 0.27 & 0.22 & $0 . \overline{-}$ & 0.52 \\
\hline 0.38 & 0.69 & 0.54 & 0.38 & 0.70 & 0.37 & 0.05 & 0.68 & 1.22 & 0.49 & 1.95 & 0.44 & 0.20 & \#\# & 0.22 & $0 . \overline{0}$ & 0.52 & 0.27 & 0.07 & 0.46 \\
\hline
\end{tabular}

treatment, although both of these are biased by the heterogeneity of the studies. Other variables that also improve outcome, which are not biased by the heterogeneity of the studies, are younger patient age and shorter duration of the disorder. In elderly patients, treatment efficacy shows no significant difference when compared with the control group. However, gender and type of treatment (pharmacological vs.

Figure 2

Pain by Level Care

\begin{tabular}{|c|c|c|c|}
\hline$\frac{\text { Gapby }}{\text { Led df Cre }}$ & Shang & attone & Conprison \\
\hline Pinzycre & Codderio 96 & UASp & Antyptine \\
\hline Pimaycre & Ginsegrg6 & WOSp & Antyptine \\
\hline Pinraycare & Herroren 98 & Vesp & Antoypline \\
\hline Pinarycre & Cartle 95 & Uesp & Antryptine \\
\hline Pintrycre & Cartle 94 & MeGllopip & Antoypline \\
\hline Pinarycre & Carthe 94 & MeGllpip & Codoerrapine \\
\hline Pintrycre & Andd OA 4 & BAp & Dibatine \\
\hline Pinerycre & Andd DS & 明p & Dibactine \\
\hline Pintrycre & coldero 96 & VASp & fluoditine \\
\hline Pinarycre & Hemonengs & USp & Moscoerice \\
\hline Pinarycare & Gufford os & UASp & Regobine \\
\hline Pinarycre & Resel 100 & UASp & Tratedo \\
\hline \multicolumn{4}{|l|}{ Pinarycre } \\
\hline Secondrycare & Vhers96 & Uesp & Aerbicuerise \\
\hline serontrycre & Straterer & LeSp & serbiceredses sot \\
\hline Serondrycare & Stradter 0 S & UASp & Aerdic erecise long \\
\hline Secontrycare & Eabing 05 & MeGllp & Besteviod issomiaterepy \\
\hline Serondrycre & Einger 05 & BPp & Etreviod issomia tereapy \\
\hline Secontry care & JogimeQ & Magllp & Bevaiod thespy \\
\hline Secontrycare & $\operatorname{Pos} 10$ & Vesp & Bigtigt \\
\hline Secontrycare & Kell 97 & VESP & Cippraticneregenet \\
\hline Serondrycae & Eingrer 05 & Meallp & Cogivive bereviard theapy \\
\hline Secontrycare & Ebingr 15 & 明p & Contive beteviard therpy \\
\hline Serntrycare & Joaimer & MeGllp & Ederciontaing \\
\hline Secontryycare & YidizO4 & UESP & Hpertaricangentherpy \\
\hline Secondrycare & Rused 94 & USp & Malcaid \\
\hline Secontrycare & Chesty 95 & VeSp & Miscloration \\
\hline Serontrycare & Grsteg 98 & WASp & Prfinde \\
\hline Secondrycare & Lentsacs & VASp & Rerebilition \\
\hline Secondrycare & Vhoes 96 & WESp & Sress-eddion tededet \\
\hline Secontrycare & Fatber 01 & VESP & Tropiston \\
\hline \multicolumn{4}{|l|}{ Secontacae } \\
\hline Ceal & & & \\
\hline
\end{tabular}

\begin{tabular}{|c|c|c|c|c|c|c|c|}
\hline \multicolumn{4}{|c|}{ Staistios for exchstudy } & \multicolumn{2}{|c|}{ Seddffinnmensad $95 \%$ C } & \multirow[b]{2}{*}{ Tho } & \multirow[b]{2}{*}{ conted } \\
\hline $\begin{array}{l}\text { Stddff } \\
\text { innmers }\end{array}$ & $\begin{array}{l}\text { Lover } \\
\text { linit }\end{array}$ & $\begin{array}{l}\text { Upper } \\
\text { linit }\end{array}$ & p-latue & & & & \\
\hline 0,73 & 0,09 & 1,37 & 0,066 & + & & 21 & 19 \\
\hline 1,64 & 0,97 & 231 & 0,000 & + & & 24 & 22 \\
\hline 0,25 & $-0,25$ & 0,5 & 0,319 & + & & 32 & $x$ \\
\hline 0,72 & 0,00 & 1,34 & 0,024 & + & & 2 & 20 \\
\hline 0,15 & $.0,24$ & 0,55 & 0,450 & + & & 78 & 3 \\
\hline 0,16 & $-0,25$ & 0,56 & 0,45 & + & & 0 & 36 \\
\hline 0,30 & 0,10 & 0,66 & 0,008 & + & & 100 & 10 \\
\hline 0,36 & 0,10 & 0,61 & 0,007 & + & & 116 & 120 \\
\hline 1,09 & 0,44 & 1,3 & 0,001 & + & & 2 & 19 \\
\hline 0,26 & $-0,25$ & $0, \pi$ & 0,317 & + & & 30 & 30 \\
\hline 0,49 & 0,20 & 0,8 & 0,001 & + & & 95 & 93 \\
\hline 0,40 & 0,0 & 0,97 & 0,033 & + & & 35 & 34 \\
\hline 0,48 & 0,30 & 0,66 & 0,000 & $\bullet$ & & 65 & 501 \\
\hline 0,76 & 0,05 & 1,4 & 0,005 & + & & 16 & 17 \\
\hline 0,20 & $-0,5$ & 0,79 & 0,314 & + & & 26 & 31 \\
\hline 0,20 & $-0,21$ & 0,80 & 0,287 & + & & $\theta$ & 31 \\
\hline 248 & 1,51 & 3,8 & 0,000 & & & 18 & 11 \\
\hline$Q, 73$ & $-0,04$ & 1,50 & 0,064 & 1 & & 18 & 11 \\
\hline 0,05 & $-0,2$ & $0, \pi$ & 0,088 & + & & 18 & 17 \\
\hline 0,04 & $-1, \infty$ & 1,10 & 0,941 & 1 & & 6 & 8 \\
\hline 0,08 & $-0,06$ & 1,2 & 0,008 & - & & 10 & 9 \\
\hline 1,74 & 0,86 & 261 & 0,000 & + & & 8 & 11 \\
\hline 0,57 & $-0,20$ & 1,33 & 0,45 & + & & 18 & 11 \\
\hline$-0,10$ & $0,0 \pi$ & 0,56 & 0,35 & + & & 18 & 17 \\
\hline 3,18 & 2,33 & $4, B$ & 0,000 & & $\longrightarrow$ & 24 & 24 \\
\hline 0,30 & $-0,2$ & 0,87 & 0,297 & + & & 24 & 24 \\
\hline 0,11 & $-0,06$ & 0,88 & 0,82 & + & & 13 & 13 \\
\hline 1,04 & 0,50 & 1,58 & 0,000 & + & & 33 & 28 \\
\hline 0,54 & 0,00 & 0,9 & 0,019 & + & & 43 & $x$ \\
\hline $0, \infty$ & 0,16 & 1,0 & 0,017 & + & & 15 & 17 \\
\hline 0,20 & 0,01 & 0,56 & 0,02 & + & & 10 & 103 \\
\hline 0,73 & 0,41 & 1,05 & 0,000 & - & & 49 & 419 \\
\hline 0,54 & 0,38 & 0,0 & 0,000 & • & & 1094 & 900 \\
\hline & & & 400 & $-2,00$ & 2,00 & $\infty$ & \\
\hline
\end{tabular}

Efficacy of the treatments allocated to both levels of care according to the type of pain in patients with fibromyalgia. 
Table 8

Influence of moderating variables on all the outcomes assessed, on the Fibromyalgia Impact Questionnaire and on the Global Function

\begin{tabular}{|c|c|c|c|c|c|c|c|c|c|c|c|c|}
\hline & \multicolumn{4}{|c|}{ All the outcome assessed } & \multicolumn{4}{|c|}{ Fibromyalgia Impact Questionnaire } & \multicolumn{4}{|c|}{ Global function } \\
\hline & $\begin{array}{l}\text { Std dif in } \\
\text { means }\end{array}$ & Lower & Upper & $\mathrm{p}$-value & $\begin{array}{l}\text { Std dif in } \\
\text { means }\end{array}$ & Lower & Upper & $p$-value & $\begin{array}{l}\text { Std dif in } \\
\text { means }\end{array}$ & Lower & Upper & p-value \\
\hline \multicolumn{13}{|l|}{$\begin{array}{l}\text { Methodological } \\
\text { quality }\end{array}$} \\
\hline 1 to 2 & 1,21 & 0.74 & 1.69 & 0.000 & & & & & 1.40 & 0.75 & 2.04 & 0.000 \\
\hline 3 to 4 & 0.57 & 0.42 & 0.72 & 0.000 & 0.66 & 0.37 & 0.95 & 0.000 & 0.58 & 0.33 & 0.83 & 0.000 \\
\hline 5 to 6 & 0.23 & 0.14 & 0.31 & 0.000 & 0.36 & 0.18 & 0.55 & 0.000 & 0.37 & 0.22 & 0.51 & 0.000 \\
\hline Overall & 0.33 & 0.26 & 0.41 & 0.000 & 0.45 & 0.29 & 0.60 & 0.000 & 0.46 & 0.33 & 0.58 & 0.000 \\
\hline \multicolumn{13}{|l|}{$\begin{array}{l}\text { Kind of } \\
\text { treatment }\end{array}$} \\
\hline Pharmacological & 0.42 & 0.32 & 0.53 & 0.000 & 0.59 & 0.29 & 0.89 & 0.000 & 0.54 & 0.33 & 0.74 & 0.000 \\
\hline $\begin{array}{r}\text { Non- } \\
\text { pharmacological }\end{array}$ & 0.63 & 0.43 & 0.83 & 0.000 & 0.52 & 0.26 & 0.79 & 0.000 & 0.52 & 0.26 & 0.79 & 0.000 \\
\hline Overall & 0.47 & 0.37 & 0.56 & 0.000 & 0.55 & 0.35 & 0.75 & 0.000 & 0.53 & 0.37 & 0.70 & 0.000 \\
\hline \multicolumn{13}{|l|}{$\begin{array}{l}\text { Length of } \\
\text { treatment } \\
\text { (weeks) }\end{array}$} \\
\hline 0 to 8 & 0.73 & 0.57 & 0.89 & 0.000 & 0.83 & 0.35 & 1.30 & 0.001 & 0.82 & 0.50 & 1.14 & 0.000 \\
\hline 9 to 16 & 0.20 & 0.11 & 0.28 & 0.000 & 0.35 & 0.20 & 0.49 & 0.000 & 0.33 & 0.20 & 0.46 & 0.000 \\
\hline 17 to 24 & 0.36 & 0.14 & 0.58 & 0.001 & 0.73 & 0.29 & 1.16 & 0.001 & 0.35 & -0.01 & 0.71 & 0.055 \\
\hline Overall & 0.31 & 0.24 & 0.38 & 0.000 & 0.42 & 0.29 & 0.55 & 0.000 & 0.40 & 0.28 & 0.51 & 0.000 \\
\hline \multicolumn{13}{|l|}{ Age } \\
\hline 30 to 39 & 1.41 & 0.95 & 1.88 & 0.000 & 1.41 & 0.97 & 1.85 & 0.000 & 1.41 & 0.97 & 1.85 & 0.000 \\
\hline 40 to 49 & 0.44 & 0.35 & 0.54 & 0.000 & 0.37 & 0.25 & 0.50 & 0.000 & 0.39 & 0.28 & 0.51 & 0.000 \\
\hline 50 to 59 & 0.50 & 0.12 & 0.88 & 0.010 & 0.99 & -0.22 & 2.20 & 0.108 & 0.99 & -0.22 & 2.20 & 0.108 \\
\hline Overall & 0.48 & 0.39 & 0.58 & 0.000 & 0.46 & 0.34 & 0.58 & 0.000 & 0.47 & 0.35 & 0.58 & 0.000 \\
\hline \multicolumn{13}{|l|}{ Women (\%) } \\
\hline$<80$ & 3.22 & 0.68 & 5.76 & 0.013 & & & & & & & & \\
\hline 80 to 89 & 0.70 & 0.49 & 0.91 & 0.000 & 0.96 & 0.30 & 1.62 & 0.004 & 0.85 & 0.46 & 1.24 & 0.000 \\
\hline 90 to 99 & 0.33 & 0.23 & 0.44 & 0.000 & 0.37 & 0.13 & 0.61 & 0.002 & 0.31 & 0.14 & 0.47 & 0.000 \\
\hline 100 & 0.40 & 0.25 & 0.55 & 0.000 & 0.50 & 0.23 & 0.78 & 0.000 & 0.50 & 0.23 & 0.78 & 0.000 \\
\hline Overall & 0.41 & 0.33 & 0.49 & 0.000 & 0.46 & 0.29 & 0.64 & 0.000 & 0.42 & 0.28 & 0.55 & 0.000 \\
\hline \multicolumn{13}{|l|}{$\begin{array}{c}\text { Duration of } \\
\text { disorder (years) }\end{array}$} \\
\hline 0 to 5 & 0.85 & 0.57 & 1.13 & 0.000 & 0.57 & 0.21 & 0.93 & 0.002 & 0.66 & 0.34 & 0.98 & 0.000 \\
\hline 6 to 10 & 0.36 & 0.27 & 0.45 & 0.000 & 0.45 & 0.26 & 0.64 & 0.000 & 0.38 & 0.22 & 0.54 & 0.000 \\
\hline 11 to 15 & 0.16 & 0.02 & 0.29 & 0.023 & & & & & & & & \\
\hline Overall & 0.36 & 0.29 & 0.43 & 0.000 & 0.49 & 0.33 & 0.65 & 0.000 & 0.45 & 0.31 & 0.58 & 0.000 \\
\hline \multicolumn{13}{|l|}{ Country } \\
\hline Germany & 0.36 & 0.17 & 0.56 & 0.000 & & & & & & & & \\
\hline
\end{tabular}


Influence of moderating variables on all the outcomes assessed, on the Fibromyalgia Impact Questionnaire and on the Global Function

\begin{tabular}{|c|c|c|c|c|c|c|c|c|c|c|c|c|}
\hline Belgium & 0.94 & 0.73 & 1.15 & 0.000 & & & & & 1.02 & 0.35 & 1.70 & 0.003 \\
\hline Brazil & 1.13 & 0.46 & 1.80 & 0.001 & 0.99 & -0.22 & 2.20 & 0.108 & 0.99 & -0.22 & 2.20 & 0.108 \\
\hline Canada & 0.35 & 0.20 & 0.50 & 0.000 & 0.38 & 0.17 & 0.59 & 0.000 & 0.29 & 0.11 & 0.46 & 0.001 \\
\hline Finland & 0.10 & -0.08 & 0.28 & 0.283 & & & & & & & & \\
\hline Netherlands & 0.09 & -0.21 & 0.39 & 0.567 & & & & & & & & \\
\hline Norway & 0.30 & -0.11 & 0.71 & 0.157 & & & & & & & & \\
\hline Sweden & 0.35 & 0.05 & 0.64 & 0.022 & 0.45 & 0.03 & 0.88 & 0.038 & 0.45 & 0.03 & 0.88 & 0.038 \\
\hline Switzerland & 0.02 & -0.21 & 0.26 & 0.836 & & & & & & & & \\
\hline Turkey & 2.19 & 1.31 & 3.08 & 0.000 & 1.41 & 0.97 & 1.85 & 0.000 & 1.41 & 0.97 & 1.85 & 0.000 \\
\hline USA & 0.39 & 0.26 & 0.51 & 0.000 & 0.34 & 0.16 & 0.53 & 0.000 & 0.36 & 0.21 & 0.50 & 0.000 \\
\hline Overall & 0.36 & 0.30 & 0.43 & 0.000 & 0.46 & 0.33 & 0.58 & 0.000 & 0.42 & 0.31 & 0.52 & 0.000 \\
\hline
\end{tabular}

psychological) are not related to outcome. These results insist on the importance of an early diagnosis of the disorder, a fact that is usually related to a younger age of the patient.

Three are three main limitations to this research:

- Heterogeneity of the disorder: there are considered to be several subgroups of patients with fibromyalgia [66], so each of them could have different treatment of choice and, consequently, the results of this study could be different for every subgroup.

- The variability of outcomes used in fibromyalgia: it is difficult to obtain a single outcome summarising the efficacy of the treatment.

- Allocation of treatments to a level of care is a subjective matter: some treatments are new and we cannot foresee which level they will be used at, while others that can theoretically be used in primary care are scarcely utilised at this level. Decisions on which level these should be allocated to had been attained by agreement among four clinicians belonging to different levels and several specialities. Another criticism could be that all the treatments allocated to primary care could also be used at a specialist level, so the comparison should have been primary care treatments vs. all fibromyalgia treatments. However, we did not used this approach because our aim was to assess what was the added value in using specialised treatments for increasing efficacy of fibromyalgia treatment.

The health system operating in Spain is quite similar to the UK and Dutch health systems and is also comparable to other European and Western health systems, with some modifications. The Spanish health system is available to all Spaniards and citizens of the EU and is completely free at all levels. For this reason, there are no economic limitations to accessibility to the system in Spain, and only geographical limitations may exist (inhabitants of small and isolated mountain villages would have more difficulty accessing large hospitals). In this sense, the results of our study could be useful for most Western health systems. Obviously, the results of the meta-analysis are more difficult to extrapolate to countries such as the USA where primary care is not the entrance gate to the system. However, the most important conclusion that can be extrapolated from the study is that family doctors can see similar improvements in their patients with their treatment than specialised clinics in the management of patients with fibromyalgia.

\section{Conclusion}

Based on this meta-analysis and despite the heterogeneity of specialised care studies, and of the other limitations described, there is no clear indicator for treating fibromyalgia in specialised care or for the development of specialised units for the treatment of this disorder. According to this study, the same moderate efficacy can be obtained in primary care settings with the routine treatments available at this level. Obviously, any new treatment could upset the balance of this comparison and, whatever the case, new research studies that are more focused on cost-efficacy analysis are necessary to confirm this data.

\section{Competing interests}

The authors declare that they have no competing interests.

\section{Authors' contributions}

JGC is the principal researcher and developed the original idea for the study. The study design was further developed by $\mathrm{JM}$ and RM. EFG and MS carried out the electronic search and reviewed the studies. EA and JM developed the statistical 
methods. All authors have read and corrected draft versions and approved the final version.

\section{Additional files}

The following Additional files are available online:

\section{Additional file 1}

A file containing the searching strategy used to select the papers included in the study.

See http://www.biomedcentral.com/content/ supplementary/ar2455-S1.doc

\section{Acknowledgements}

This study was supported in part by Grant 05/90243 of the Spanish Fondo de Investigaciones Sanitarias titled Assessment of the efficacy of treatment of fibromyalgia according to level of care: A systematic review (Evaluación de la eficacia del tratamiento de la fibromialgia según nivel de atención. Una revisión sistemática). We thank "Red de Investigación en Actividades de Prevención y Promoción de la Salud" (Research Network on Preventative Activities and Health Promotion) (REDIAPP-G06128), Nodo de Aragón, for its support in the development of this study. The funding sources had no role in the collection, analysis or interpretation of the data, or in the decision to submit the manuscript for publication.

\section{References}

1. Wolfe F, Smythe HA, Yunus MB, Bennet RM, Bombardier C, Goldenberg DL, Tugwell P, Campbell SM: The American College of Rheumatology 1990 Criteria for the classification of fibromyalgia. Report of the Multicenter Criteria Committee. Arthritis Rheum 1990, 33:160-172.

2. Hudson Jl, Pope HG Jr: The relationship between fibromyalgia and major depressive disorder. Rheum Dis Clin North Am 1996, 22:285-303.

3. Wolfe F, Ross K, Anderson J, Russell IJ: The prevalence and characteristics of fibromyalgia in the general population. Arthritis Rheum 1995, 38:19-28.

4. Wolfe F: Fibromyalgia, the clinical syndrome. Rheum Dis Clin NA 1989, 15:1-18

5. Wolfe F, Anderson J, Harkness D, Bennet RM, Caro XJ, Goldenberg DL, Russell IJ, Yunus MB: Health status and disease severity in fibromyalgia: results of a six-center longitudinal study. Arthritis Rheum 1997, 40:1571-1579.

6. Arnold LM, Keck PE, Welge JA: Antidepressant treatment of fibromyalgia. A meta-analysis and review. Psychosomatics 2000, 41:104-113.

7. O'Malley PG, Balden E, Tomkins G, Santoro J, Kroenke K, Jackson JL: Treatment of fibromialgia with antidepressants. A metaanalysis. J Gen Intern Med 2000, 15:659-666.

8. Tofferi JK, Jackson JL, O'Malley PG: Treatment of fibromialgia with cyclobenzaprine: a meta-analysis. Arthritis Rheum 2004, 51:9-13.

9. Sim J, Adams N: Systematic review of randomized controlled trials of nonpharmacological interventions for fibromialgia. Clin J Pain 2002, 18:324-336.

10. Mayhew E, Ernst E: Acupuncture for fibromialgia - a systematic review of randomized clinical trials. Rheumatology 2007, 46:801-804.

11. Moher D, Cook DJ, Eastwood S, Olkin I, Rennie D, Stroup DF: Improving the quality of reports of meta-analyses of randomised controlled trials: the QUOROM statement. Quality of Reporting of Meta-analyses. Lancet 1999, 354:1896-1900.
12. Pasquina $P$, Tramer $M R$, Walder $B$ : Prophylactic respiratory physiotherapy after cardiac surgery: systematic review. $B M J$ 2003, 327:1379.

13. Elia N, Tramer MR: Ketamine and postoperative pain - a quantitative systematic review of randomised trials. Pain 2005, 113:61-70.

14. Carette S, Bell MJ, Reynols WJ, Haraqui B, McCain G, Bykerk V Edworthy SM, Baron M, Koehler BE, Fam AG: Comparison of amitriptyline, cyclobenzaprine, and placebo in the treatment of fibromyalgia. A randomized, double-blind clinical trial. Arthritis \& Rheumatism 1994, 37:32-40.

15. Russell IJ, Michael JE, Flechas JD, Abraham GE: Treatment of fibromyalgia syndrome with super malic: A randomized, double blind, placebo controlled, crossover pilot study. J Rheumatol 1995, 22:953-958.

16. Wolfe F, Cathey MA, Hawley DJ: A double-blind placebo controlled trial of fluoxetine in fibromyalgia. Scand $J$ Rheumatol 1994, 23:255-259.

17. Carette S, Oakson G, Guimont CH, Steriade M: Sleep electroencephalography and the clinical response to amitriptyline in patients with fibromyalgia. Arthritis \& Rheumatism 1995, 38:1211-1217.

18. Chesky KS, Russell IJ, Lopez Y, Kondraske GV: Fibromyalgia tender point pain: A double blind, placebo-controlled pilot study of music vibration using the music vibration table. J Musculosk Pain 1997, 5:33-52.

19. Goldenberg D, Maysky M, Mossey C, Ruthazer R, Schmid C: A randomized double-blind crossover trial of fluoxetine and amitriptyline in the treatment of fibromyalgia. Arthritis \& Rheumatism 1996, 39:1852-1859.

20. Ginsberg F, Mancaux A, Joos E, Vanhove Ph, Famacy JP: A randomized placebo-controlled trial of sustained-release amitriptyline in primary fibromyalgia. J Musculosk Pain 1996 4:37-47.

21. Moldofsky H, Lue F, Mously C, Rhot-Schechter R, Reynolds WJ: The effect of zolpidem in patients with fibromyalgia: A dose ranging, double blind, placebo controlled, modified crossover study. J Rheumatol 1996, 23:529-533.

22. Vlaeyen JW, Teeken-Gruben NJ, Goosens EJ, Ritten M, Pelt R, Hugo van Eek Heuts P: Cognitive-educational treatment of fibromyalgia: A randomized clinical trial. I. Clinical effects. J Rheumatol 1996, 23:1 237-1245.

23. Wigers $\mathrm{SH}$, Stiles TC Vogel A: Effects of aerobic exercise versus stress management treatment in fibromylgia. Scand $J$ Rheumatol 1996, 25:77-86.

24. Pearl S, Lue F, McLean A, Heslegrave R, Reynolds WL, Moldofsky $\mathrm{H}$ : The effects of bright light treatment on the symptoms of fibromyalgia. J Rheumatol 1996, 23:896-902.

25. Kelli L, Moez H, Rajwani H, Rocco C: The efficacy of chiropractic management of fibromyalgia patients: a pilot study. J Manipul Physiol Ther 1997, 20:389-399.

26. Hannonen $\mathrm{P}$, Malminiemi K, Yli-Kerttula U, Isomeri R, Roponen $\mathrm{P}$ : A randomized, double-blind, placebo-controlled study of moclobemide and amitriptyline in the treatment of fibromyalgia in females without psychiatric disorder. $\mathrm{Br} J$ Rheumatol 1998, 37:1279-1286.

27. Yavuzer G, Küçükdeveci A, Arasil T, Elhan A: Moclobemide treatment in primary fibromyalgia syndrome. Eur $J$ Phys Med Rehabil 1998, 8:35-38.

28. Ginsberg F, Joos E, Géczy J, Bruhwyler J, Vanderkerckhove K, Famaey JP: A pilot randomized placebo-controlled study of pirlindole in the treatment of fibromyalgia. J Musculosk Pain 1998, 6:5-17.

29. Russel J, Kamin M, Bennett R, Schnitzer T, Grenn J, Katz W: Efficacy of tramadol in treatment of pain in fibromyalgia. $J$ Clin Rheumatol 2000, 6:250-257.

30. Heyman RE, Helfenstein M, Feldman D: A double-blind, randomized, controlled study of amitriptyline, nortriptyline and placebo in patients with fibromyalgia. An analysis of outcome measures. Clin Experiment Rheumatol 2001, 19:697-702.

31. Färber L, Stratz TH, Brückle W, Späth M, Pongratz D: Short-term treatment of primary fibromyalgia whit the 5-HT3-receptor antagonist tropisetron. Results of a randomized double-blind, placebo-controlled multicenter trial in $\mathbf{4 1 8}$ patients. Int J Clin Pharm Res 2001, 21:1-13.

32. Gowans SE, Hueck A, Voss S, Silaj A, Abbey SE, Reynolds WJ: Effect of randomized, controlled trial of exercise on mood and 
physical function in individuals with fibromyalgia. Arthrit Care \& Res 2001, 45:519-529.

33. Mannerkorpi K, Nyberg B, Ahlmen M, Ekdahi Ch: Pool exercise combined with an education program for patients with fibromyalgia syndrome. A prospective, randomized study. J Rheumatol 2000, 27:2473-2481.

34. Gür A, Karakoc M, Nas K, Cevik R, Sarac AJ, Ataoglu S: Effects of low power laser and low dose amitriptyline therapy on clinical symptoms and quality of life in fibromyalgia: a single-blind, placebo-controlled trial. Rheumatol Int 2002, 22:188-193.

35. Joaquim J, Soares F, Grossi G: A randomized, controlled comparison of educational and behavioural interventions for women with fibromyalgia. Scand J Occupat Ther 2002, 9:35-45.

36. King S, Wessel J, Bhambhani Y, Sholter D, Maksymowych W: The effects of exercise and education, individually or combined, in women with fibromyalgia. J Rheumatol 2002, 29:2620-2627.

37. Lemstra M, Olszynski P: The efficacy of multidisciplinary rehabilitation in the treatment of fibromyalgia. Clin J Pain 2005, 21:166-174.

38. Schachter C, Busch A, Peloso P, Sheppard MS: Effects of short versus long bouts of aerobic exercise in sedentary women with fibromyalgia: A randomized controlled trial. Phys Ther 2003, 83:340-358.

39. Arnold L, Lu L, Crofford L, Wohlreich M, Detke M, lyengar S, Goldstein $D$ : Double-blind, multicenter trial comparing duloxetine with placebo in the treatment of fibromyalgia patients with or without major depressive disorder. Arthrit \& Rheum 2004, 50:2974-2984

40. Yildiz S, Kiralp M, Akin A, Keskin I, Ay H, Dursun H, Cimsit M: A new treatment modality for fibromyalgia syndrome: hyperbaric oxygen therapy. J Internat Med Res 2004 32:263-267.

41. Crofford L, Rowbotham M, Mease P, Russell I, Dworkin R, Corbin A, Young J, LaMoreaux L, Martin S, Sharma U, the pregabalin 1008-105 Study group: Pregabalin for the treatment of fibromyalgia syndrome. Arthritis \& Rheumatim 2005, 52:1264-1273.

42. Arnold L, Rosen A, Pritchett Y, D'Souza D, Goldstein D, lyengar S, Wernicke J: A randomized, double blind, placebo-controlled trial of duloxetine in the treatment of women with fibromyalgia with or without major depressive disorder. Pain 2005, 119:5-15.

43. Gendreau M, Thorn M, Gendreau J, Kranzler J, Ribeiro S, Gracely $R$, Wiliams $D$, Mease $P$, McLean S, Lauw D: Efficay of milnacipran in patients with fibromyalgia. J Rheumatol 2005, 32:1975-1985.

44. Finckh A, Berner I, Aubry-Rozier B, Kai-Lik So A: A randomized controlled trial of dehydroepiandrosterona in menopausal women with fibromyalgia. J Rheumatol 2005, 32:1336-1340.

45. Holman A, Myers R: A randomized, double-blind, placebo-controlled trial of pramipexole, a dopamine agonist, in patients with fibromyalgia receiving concomitant medications. Arthitis \& Rheumatism 2005, 5:2495-2505.

46. Edinger J, Wohlgemuth, Krystal A, Rice J: Behavioral insomnia therapy for fibromyalgia patients. Arch Intern Med 2005, 165:2527-2535

47. Buskila D, Abu-Shakra M, Neumann L, Odes L, Shneider E, Fkusser D, Sukenik S: Balneotherapy for fibromyalgia at the Dead Sea. Rheumatol Int 2001, 21:105-108.

48. Melzack R: The McGill Pain Questionnaire: major properties and scoring methods. Pain 1975, 1:277-299.

49. Cleeland CS, Ryan KM: Pain assessment: global use of the Brief Pain Inventory. Ann Acad Med Singapore 1994, 23:129-138.

50. Sriwatanakul K, Kelvie W, Lasagna L: Studies with different types of visual analog scales for measurement of pain. Clin Pharmacol Ther 1983, 34:234-239.

51. Ware JE, Snow KK, Kosinski M, Grandek B: SF-36 health survey manual and interpretation guide Boston: The Health Institute, New England Medical Center; 1993.

52. Buckhardt CS, Archenholtz B, Bjelle A: Measuring the quality of life of women with rheumatoid arthritis of systemic lupus erythematosus: a Swedish version of the quality of life scale. Scand J Rheumatol 1992, 21:190-195.

53. Beck AT, Steer RA, Ball R, Rainieri W: Comparison of Beck Depression Inventories IA and II in psychiatric outpatient. J Pers Asses 1996, 67:588-597.
54. Zigmond A, Snaith RP: The Hospital anxiety and depression scale. Acta Psychiatric Scand 1983, 67:361-370.

55. Hamilton M: A rating scale for depression. J Neurol Neurosurg Psychiatric 1960, 23:56-62.

56. Speilberger CD: State-trait Anxiety Inventory for adults Palo Alto: Mind Garden; 1980.

57. Guy W, ECDEU: Assessment Manual for Psychopharmacology Revised. Rockville: US Department of Health, Education and Welfare publication (ADM), National Institute of Mental Health 1976:218-22.

58. Russell IJ, Viprao GA, Morgan WW, Bowden CL: Is there a metabolic basis for the fibrositis syndrome? Am J Med 1986 81:50-56.

59. Belza B, Henke C, Epstein W, Gilliss C: Correlates of fatigue in older adults with rheumatoid arthritis. Nurs Res 1993 42:93-99.

60. Burckhardt CS, Clarck SR, Bennet RM: The fibromyalgia impact questionnaire: development and validation. J Rheumato/ 1991, 18:728-733.

61. Bergner M, Bobbitt RA, Carter WB, Bilson BS: The Sickness Impact Profile: development and final revision of a health status measure. Med Care 1981, 19:787-805.

62. Cohen J: Statistical power analysis for the behavioural sciences 2nd edition. Hillsdale: Lawrence Erlbaum Associates; 1988.

63. Higgins JPT, Thompson SG, Deeck JJ, Altman DG: Measuring inconsistency in meta-analysis. BMJ 2003, 327:557-560.

64. Van Wilgen CP, Bloten H, Oeseburg B: Results of a multidisciplinary program for patients with fibromyalgia implemented in the primary care. Disabil Rehabil 2007, 29:1207-1213.

65. Alamo MM, Moral RR, Pérula de Torres LA: Evaluation of a patient-centred approach in generalized musculoskeletal chronic pain/fibromyalgia patients in primary care. Patient Educ Couns 2002, 48:23-31.

66. Giesecke T, Williams DA, Harris RE, Cupps TR, Tian X, Tian TX Gracely $\mathrm{RH}$, Clauw DJ: Subgrouping of fibromyalgia patients on the basis of pressure-pain thresholds and psychological factors. Arthrit Rheum 2003, 48:2916-2922. 